\title{
Briefly
}

\section{SPOTLIGHT ON BIRDS}

\section{North America has lost 3 billion birds since 1970. .}

A new study, quantifying for the first time the total decline in bird populations in the continental USA and Canada, states that nearly 3 billion birds have been lost since 1970. This equates to an average reduction of $29 \%$ across species, more than one in four birds. Researchers analysed population trends for 529 bird species in North America and found 90\% of declines occurred in just 12 families. Grassland bird populations show the biggest decrease with $53 \%$, but declines permeate every biome. Habitat loss is a predominant driving factor and the results indicate that we are consistently eroding the foundations that support the planet's ecosystems. The declines are a strong signal that our human-altered landscapes are losing their ability to support birds, an indicator of a coming collapse of the overall environment. Conservation strategy needs to move beyond saving individual threatened species, to a more holistic approach focused on whole ecosystems and biomes.

Sources: Science (2019) doi.org/10.1126.aaw1313 \& Cornell University (2019) allaboutbirds. org/vanishing-1-in-4-birds-gone

\section{... and large scale illegal bird killing in the Middle East}

A new study estimated for the first time the scale and extent of the illegal killing and taking of wild birds in the Arabian peninsula, Iraq and Iran. Using a diverse range of data sources and incorporating expert knowledge, the researchers estimate that 1.7-4.6 million birds of at least 413 species may be killed or taken illegally each year in this region, many of them on migration. This is likely to be an underestimate as data were unavailable for parts of the region. Birds are killed or taken mostly by shooting or trapping, primarily for sport, but also for food, often as a delicacy. Researchers call for immediate action by relevant national authorities, enforcement bodies and other stakeholders to implement a zero tolerance approach to illegal killing and removal of birds across the region.

Sources: Sandgrouse (2019) osme.org/sites/ default/files/pdf/Sandgrouse41-2-Brochetetal.pdf \& BirdlLife International (2019) birdlife.org/worldwide/news/scale-illegalbird-killing-middle-east-revealed-first-time

\section{Loud aeroplane noise makes birds aggressive}

Noise from aeroplanes landing and taking off causes birds to become more aggressive and potentially impairs their hearing. Common chiffchaffs living close to airports were five times more likely to attack a speaker emitting bird song than their counterparts inhabiting quieter environments. Birds near airports are exposed to extreme noise levels that interfere with their ability to communicate with potential mates or rivals. The birds at the two airports studied also sang at a lower frequency, indicating possible hearing loss. Aircraft noise can reach 100 decibels at a distance of $100 \mathrm{~m}$, which can cause permanent hearing damage not only in birds, but also in humans. The findings provide new insight for airport planners and have implications for conservation and environmental regeneration projects.

Sources: Journal of Animal Ecology (2019) doi.org/10.1111/1365-2656.13059 \& British Ecological Society (2019) britishecological society.org/angry-birds-loud-aeroplanenoise-causes-birds-become-aggressive

\section{Artificial intelligence tracks bird migrations from weather radar}

Some bird migrations are so large that they appear on weather radar, filling the skies during spring and autumn nights. Although bird-related information stored in the weather radar record could support ornithological research, scientists have until now lacked the tools to effectively access it. Earlier studies had identified patterns that could differentiate weather phenomena from bird formations, but the scale of the data, hundreds of millions of images, bottlenecked the research. MistNet, a new tool developed by researchers at the University of Massachusetts and the Cornell Lab of Ornithology, among others, leverages machine learning to analyse data more efficiently. Weather records reach decades into the past, allowing the researchers to measure historical bird migrations. With the results from MistNet, scientists were able to illustrate and animate intensive migration areas in the USA, estimate flying velocity and more. They hope MistNet will enable a range of science and conservation applications.

Sources: Methods in Ecology and Evolution (2019) doi.org/10.1111/2041-210X.13280 \& HPC Wire (2019) hpcwire.com/2019/o8/ 29/ai-clears-the-skies-for-tracking-birdmigrations

\section{Bearded vultures soar again in Alps after breeding scheme}

In the summer of 2019, as the snow melted across the Alps, a record 35 bearded vulture chicks were expected to leave their nests and take to the skies to patrol their mountain home, in one of the most successful wildlife comebacks of recent times. Bearded vultures Gypaetus barbatus were hunted to extinction in the Alps in the early 2oth century. People referred to them as the devil bird, believing that they would carry off small children and sheep. But attitudes have changed and the vultures are now valued for their vital ecosystem role. They have made a dramatic return, with the support of conservationists and local stakeholders. A captive breeding and reintroduction project began in the late 1980 s and there are now a total of 250 birds, including 50 breeding pairs, in the Alps. José Tavares, director of the Vulture Conservation Foundation, explained that the reintroduced birds have all been bred in captivity rather than captured and relocated from elsewhere.

Source: The Guardian (2019) theguardian. com/environment/2019/aug/o2/beardedvultures-soar-again-in-alps-after-breedingscheme

\section{Mixed findings in State of Canada's Birds 2019 report}

Humans have had a dramatic impact on Canada's bird populations over the past 50 years, according to a major new publication. The second State of Canada's Birds report has produced a mixed picture for population trends among various bird families. Wildfowl and birds of prey have increased by $150 \%$ and $110 \%$, respectively. Ducks and other wetland birds have benefited from ongoing investment in conservation and cooperative stewardship of wetlands and surrounding areas. Six species of geese have expanded in number by an average of $360 \%$ since 1970. Aerial insectivores, on the other hand, are now mirroring the declines that birds of prey showed in the 1950s; probably a result of agricultural intensification, declining insect populations and a changing climate. Canada's shorebirds are struggling too, with long-distance migrants faring the worst. Species wintering in the country face fewer threats and are faring better overall (up 34\%), except for species that depend on tree seeds and fruit (down 39\%).

Source: Bird Guides (2019) birdguides.com/ news/mixed-findings-in-state-of-canadasbirds-2019-report 


\section{INTERNATIONAL}

\section{Humpback whale recovery relies on protection of food source}

After first settling on South Georgia and the South Sandwich Islands in 1904, the whaling industry processed 175,250 cetaceans in $6 \mathrm{dec}$ ades, driven by the demand for whale oil products. By 1965, whale numbers had dropped too low for the industry to turn a profit and the whaling stations were abandoned. The western South Atlantic humpback whale population was driven to the brink of extinction during the intensive whaling period, but has since made a remarkable comeback. Having dropped to just 450 individuals by the mid 1950s, the population is now estimated to be close to $25,000,93 \%$ of its pre-exploitation size. However, continued recovery is not guaranteed. Although commercial whaling remains banned, scientists say climate change and industrial-scale fishing are threatening the whale's main food source, Antarctic krill. To mitigate those threats, conservationists are campaigning for the establishment of a marine protected area around the islands, including a ban on industrial krill fishing.

Source: The Pew Charitable Trusts (2019) pewtrusts.org/en/research-and-analysis/ articles/2019/10/16/humpback-whalesrecovery-underscores-need-to-safeguardfeeding-grounds

\section{World's nations gathered to tackle wildlife extinction crisis}

The summit of the Convention on International Trade in Endangered Species (CITES) took place in August 2019. In the wake of unprecedented plant and wildlife population declines, this meeting aimed to tackle the illegal wildlife trade, a market estimated to be worth USD 7-23 billion per year. The CITES agreement regulates international wildlife trade and punishes countries that breach it. One species of focus was the vaquita, a porpoise native to Mexico, with only 19 individuals left. The vaquita is often bycatch when fishers target totoaba, a large fish whose swim bladder can sell illegally for USD $20,000 / \mathrm{kg}$ in China because of its supposed medicinal properties. Because of the vaquita's rapid demise, many were calling for sanctions against Mexico. Another noteworthy proposal from the meeting was to add an extinct species, the woolly mammoth, to the list of species with trade restrictions, to prevent the trade of elephant ivory disguised as mammoth ivory. Source: The Guardian (2019) theguardian. com/environment/2019/aug/17/frogtortoises-cites-wildlife-summit

\section{Reflections on the new television series Our Planet}

David Attenborough has been a strong voice for wildlife for decades but the nature documentaries he narrates have been criticized as shying away from stark representations of the devastation humans can cause. One of his latest documentaries, Our Planet, has been widely promoted as representing a new direction and putting the threats facing nature front and centre to the narrative. A new study compared the scripts of Our Planet and three previous high-profile David Attenborough documentary series and showed that Our Planet discusses both threats (such as climate change) and conservation successes (such as a whale population recovery following a hunting ban) far more often than the older documentaries. Visually, however, the new series is very similar to previous offerings: nature is mostly shown as pristine, and the impacts of people on the natural world seldom appear. The study's authors discuss how viewers may be affected by the impression that much of nature is still unspoilt, and the potential ways in which watching such documentaries could lead to people reducing their environmental footprints.

Source: People and Nature (2019) doi.org/ 10.1002/pan3.10052

\section{Lessons from Antarctic marine protection treaty}

A landmark multinational agreement protecting Antarctica's Ross Sea offers valuable lessons for similar global conservation pacts in the future, according to a new analysis. The Ross Sea Region Marine Protection Area was adopted by the international community, including 24 member states and the EU, in October 2016 after $>5$ years of negotiations. The agreement was not without challenges, but shows that conservation of the global commons is possible. It aims to preserve vital biodiversity in the Southern Ocean, with the Ross Sea being regarded as one of the richest marine ecosystems. However, despite widespread praise for the establishment of the world's largest marine protected area, its conservation value remains to be seen. The finally agreed protected area was $70 \%$ off limits to fishing, but some fishing is still allowed, including in areas critical for wildlife. Furthermore, the protected area is set to expire in 35 yearsshorter than the life histories of some of the animals it set out to preserve.

Sources: Conservation Letters (2019) dx.doi. org/10.1111/conl.12676 \& Phys.org (2019) phys.org/news/2019-09-antarctic-marinetreaty-lessons-global.html
Landmark United Nations report warns of rapid sea level rise. .

Cities from New York to Shanghai could see regular flooding, as sea levels rise faster than previously thought. Glaciers and ice sheets from the Himalayas to Antarctica are rapidly melting, and fisheries that feed millions of people are shrinking. These are just some of the impacts that emissions of greenhouse gases have already triggered across the planet's oceans and frozen regions, according to a new landmark report from the United Nations' Intergovernmental Panel on Climate Change (IPCC). More than 100 scientists from 36 countries worked on the Special Report on the Ocean and Cryosphere in a Changing Climate. It is the last of three special IPCC reports following the urgent report from October 2018 that showed the world may only have until 2030 to keep global warming below 1.5 degrees, and a report from August 2019 on climate impacts to the planet's lands. The report is the first IPCC-produced examination of the furthest corners of the Earth, from the highest mountains in remote polar regions to the deepest oceans. It compiles evidence showing that human-induced warming is rapidly taking the planet down an uncharted path. Source: CNN (2019) edition.cnn.com/2019/ o9/25/world/un-ipcc-report-oceans-andice-climate-change/index.html

\section{... and millions march in global climate strike}

On 27 September 2019, the youth-led worldwide climate strike occurred, with events attended by $>6$ million people across the globe. The purpose of these strikes was to demand immediate and meaningful action by world governments to address the issue of the climate crisis. Strikers also campaigned for an end to fossil fuel use. Noted youth climate leader Greta Thunberg was present at the strike in Montreal, Canada. She was joined by an estimated 315,000 people, making the event in Montreal one of the most attended environmental marches in history. Attendants' motivations included a desire to connect with others who care about the environment, raise awareness around the topic of climate change, and ensure intergenerational justice, safeguarding the future for generations to come. School boards around the world supported students who chose to attend the strike and worked to ensure students received no academic penalty for taking part in the protests.

Source: Excalibur (2019) excal.on.ca/ millions-march-in-the-global-climatestrike 


\section{EUROPE}

\section{Germany launches EUR 100 million insect protection plan}

In 2017, researchers reported a dramatic loss of insects in Germany's nature reserves: $76 \%$ less biomass over 3 decades. Spurred by wide public concern about the findings, the federal government announced in September 2019 a EUR 100 million action plan for insect protection, which includes at least EUR 25 million per year for research and monitoring of insect populations. The plan proposes that several insect-rich habitats be protected, including meadows, hedges, semi-wild fruit orchards and stone walls in the countryside. Light pollution, which can disrupt nocturnal insects' behaviour, is also addressed. In addition, the plan promises to phase out all use of glyphosate, the world's most common weed killer, by December 2023. The broad-spectrum herbicide often ends up killing the native plants that insects rely on. Approval of new pesticides will have to take into account effects on biodiversity. The plan also calls for development of a nationwide insect monitoring network and increased research into possible causes for the observed declines and ways to reverse them.

Source: Science Magazine (2019) sciencemag. org/news/2019/o9/100-million-germaninsect-protection-plan-will-protecthabitats-restrict-weed-killers

\section{Iceland's Okjokull glacier commemorated with plaque}

Mourners have gathered in Iceland to commemorate the loss of Okjokull, which once sat atop Ok volcano ('jokull' is Icelandic for 'glacier') and has died at the age of c. 700 years. The glacier was officially declared dead in 2014 when it was no longer thick enough to move; it is now reduced to a small patch of ice. After opening remarks by Iceland's prime minister, mourners walked up the volcano north-east of the capital Reykjavik to lay a plaque which carries a letter to the future. It reads 'Ok is the first Icelandic glacier to lose its status as glacier. In the next 200 years all our main glaciers are expected to follow the same path. This monument is to acknowledge that we know what is happening and what needs to be done. Only you know if we did it.' The dedication, written by Icelandic author Andri Snaer Magnason, ends with the date of the ceremony and the concentration of carbon dioxide in the air globally: 415 parts per million.

Source: BBC (2019) bbc.co.uk/news/worldeurope-49345912

\section{European bison return to Transylvania. .}

A new herd of European bison has been introduced to Transylvania. The species was hunted to the brink of extinction in the early 2oth century, and fewer than 60 individuals remained, all in captivity. In the USA, the American bison's population fell below 6oo. Yet both species have since been nursed back to health. Herds have already been re-established in Poland and Belarus. Eastern Europe's ecologically diverse wildflower meadows and old-growth forests provide near-perfect conditions for bison and other scarce species. Wild bees, dragonflies, glow-worms, and the birds that feed on them, are threatened by intensive agriculture in western Europe but still thrive here. In the communist era, wildernesses benefited from a reluctance to farm agriculturally marginal land. More recently, rural areas have seen mass emigration since Romania joined the EU. The human population of Caras-Severin county, where the newly introduced herd will roam, fell from 380,000 in 1990 to 280,000 in 2019.

Source: The Economist (2019) economist. com/europe/2019/08/22/an-ancient-beastreturns-to-transylvania

\section{... and Pine martens reintroduced to England}

A few hundred years ago, the beautiful pine marten was found all over the British Isles, but over the 18th and 19th centuries gamekeepers at shooting estates largely wiped them out as they sought to protect their stocks of game birds. By the early 2oth century, they were almost completely extinct across England and Wales, with small remnant populations in the remotest Scottish highlands. Since then, pine martens have made a significant comeback in Scotland, but had not made it to England, until last year. In August 2019, 18 pine martens were humanely trapped in a woodland near Inverness, and then taken down to Gloucestershire, where they were released in a secret location within the Forest of Dean. Pine martens play a vital role in the balance of woodland ecosystems, not least because they prey on the non-native grey squirrel. The successful reintroduction is the result of years of planning to establish a source population to bring pine martens back to England. The work was carried out by Gloucestershire Wildlife Trust, together with Forestry England, Vincent Wildlife Trust and Forest Research.

Source: The Independent (2019) indepen dent.co.uk/environment/pine-martensreintroduced-england-rewilding-forestof-dean-species-a9129746.html

\section{Over half of Europe's endemic trees face extinction}

Over half of Europe's endemic tree species are threatened with extinction, according to assessments of the state of the continent's biodiversity published in September 2019 by the IUCN. The introduction of invasive species, unsustainable logging and urban development are key threats to tree species across Europe. The newly published European Red List of Trees evaluated the conservation status of all 454 tree species native to the continent, and found that two fifths $(42 \%)$ are regionally threatened with extinction. Among Europe's endemic trees 58\% were found to be threatened, and 15\% (66 species) assessed as Critically Endangered. The biggest threats include pests and diseases but also invasive plants, which were introduced by humans and compete with native tree saplings. Species in the Sorbus genus, which includes the Crimean rowan and mountain-ash, are particularly affected, with three-quarters of Europe's 170 Sorbus species assessed as threatened. The iconic horse-chestnut has been assessed as Vulnerable following declines caused by the invasive leaf-miner moth, which damages the trees' leaves, adding to pressures from logging, forest fires and tourism.

Source: IUCN (2019) iucn.org/news/species/ 201909/over-half-europes-endemic-trees-

face-extinction

\section{UK declares first national marine park in Plymouth}

Plymouth Sound is set to be designated the UK's first national marine park, with the aim of protecting the area's estimated 1,000 species of marine life and vast seafaring economy. Similar to a terrestrial national park, the site at Plymouth Sound will be a protected area of the ocean. City leaders, experts in the marine sector and partners from the public, private and voluntary sectors signed a pledge in September 2019, demonstrating their support for the protection plans. Plymouth Sound is already a protected habitat for $>1,000$ species of fish and other marine animal life. The park will aim to promote marine conservation, engineering and research, while taking into account the needs of the industries present in the area such as fishing and military ports. It will also preserve the memory of the pioneering sailings that set sail from Plymouth, which included the Mayflower in 1620 and the HMS Beagle in 1831, on which Charles Darwin travelled.

Source: Sky News (2019) news.sky.com/ story/plymouth-set-to-be-the-home-ofuks-first-national-marine-park-11808533 


\section{AFRICA}

\section{Ethiopia plants $\mathbf{3 5 0}$ million trees in 1 day}

Approximately 350 million trees have been planted in a single day in Ethiopia, according to a government minister. The planting was part of a national 'green legacy' initiative to grow 4 billion trees in the country during the summer of 2019 by encouraging every citizen to plant at least 40 seedlings. Public offices have reportedly been shut down to allow civil servants to take part. The project aims to tackle the effects of deforestation and climate change in the drought-prone country. According to the United Nations, Ethiopia's forest coverage was just $4 \%$ in the 2000 , down from $35 \%$ a century earlier. The previous world record for the most trees planted in 1 day stood at 50 million, held by India since 2016. Trees can not only help mitigate climate change, they also have benefits in combating desertification and land degradation, particularly in arid countries, and provide food, shelter, fuel, fodder, medicine, materials and protection of the water supply. The impressive planting effort is part of a complex challenge to take account of the short- and long-term needs of both trees and people. Source: The Guardian (2019) theguardian. com/world/2019/jul/29/ethiopia-plants250m-trees-in-a-day-to-help-tackleclimate-crisis

\section{Has Kenya's plastic bag ban worked?}

Two years ago Kenya introduced a ban on plastic carrier bags, making their manufacturing, sale and distribution illegal, with fines for non-compliance of up to GBP 32,000 , or 10 years in prison. The ban came after tens of millions of bags had been used annually in the country, without an effective waste management system. Plastic bags in the environment caused pollution, clogged up drainage systems and were being ingested by grazing cattle. The ban has largely been considered a success, with supermarkets and many shops no longer handing out plastic bags, $80 \%$ of the population using alternatives, and a reduction in visible environmental pollution. However, some small traders have been using smaller bags made of clear plastic, possibly smuggled into the country from neighbouring Uganda and Somalia. International smuggling is also a problem reported by Rwanda, which banned plastic bags in 2008, and Morocco, which started enforcing a ban in 2017. Tanzania also implemented a ban in June 2019. Source: BBC (2019) bbc.co.uk/news/worldafrica- 49421885
Fighting illegal fishing in Liberia...

Liberia has the longest coastline in West Africa and the government wants to improve food security and ensure the livelihoods of the country's 33,000 fishers. Fish stocks are under threat from industrial vessels that illegally enter areas dedicated to artisanal fishing, causing overexploitation and leading to conflicts. Industrial fishing vessels are catching vast amounts of fish, many as unwanted by-catch. Their nets can encircle a school of tuna, and everything else within them, for $>1 \mathrm{~km}$. Since 2017 , however, when the Liberian army started joint at-sea patrols with the ocean conservation organization Sea Shepherd, the country has turned into a regional leader in the fight against illegal fishing. The organization provides the Liberian coastguard with a ship, small boats and a crew largely comprised of volunteers. Fifteen fishing vessels have since been held for illegal fishing and other fisheries crimes, whereas only three arrests were made in the 7 years prior to this partnership. Most of the arrested boats are from China or other Asian countries, but some also from Europe. The UN Food and Agriculture Organization estimates illegal, unreported and unregulated fishing accounts for up to 26 million $t$ of fish per year, valued at USD $10-23$ billion, which is $>15 \%$ of the world's fish capture.

Source: New Internationalist (2019) newint. org/features/2019/08/14/how-fight-illegalfishing

\section{... and invasive cacti in Namibia}

Cochineal and mealybug insects have been released in and around Windhoek, Namibia, to fight the spread of invasive devil's rope and the lady of the night cacti. These form dense and impenetrable thickets, making it impossible for both humans and animals to access the areas they cover. This is a serious problem, because indigenous plants and animals are excluded and land becomes less valuable because of the reduced grazing capacity. The insects feed specifically on these cactus species and it is hoped that they will slowly kill them off. Scientists from Rhodes University in Windhoek say this form of biological weed control is safe and will only kill the non-native cacti, but the process can take years rather than weeks or months. This is the first time biological control methods are being used in Namibia in over 30 years. If successful, it could inspire the use of similar approaches for many other problematic weeds in the country.

Source: The Namibian (2019) namibian. com.na/82788/read/Biological-fightagainst-invasive-cacti

\section{Illegal pet trade driving cheetahs closer to extinction}

There are fewer than 7,500 cheetahs left in the wild, according to the Cheetah Conservation Fund. However, another 1,00o are being held captive in private hands in Gulf countries, where many are bought and sold in illegal online sales. A study documented 1,367 cheetahs for sale on social media platforms during January 2012-June 2018, largely from Arab Gulf states. Somaliland is the main transit route for cheetah trafficking in the Horn of Africa, with animals being smuggled across the country's porous border, then stowed away in cramped crates or cardboard boxes on boats and sent across the Gulf of Aden to their destination in Arab mansions. There they are flaunted as status symbols and paraded around in social media posts. Although many Gulf states, including the United Arab Emirates and Saudi Arabia, ban the private ownership and sale of wild animals, enforcement is lax. Some 300 young cheetahs are trafficked out of Somaliland every year; three out of four die during the trip, and the majority of captive cheetahs die within 1-2 years of being captured. Conservationists fear that if the current rate of trafficking continues, the cheetah population in the region could soon be extirpated.

Source: CNN (2019) edition.cnn.com/2019/ o8/28/africa/somaliland-cheetahs-gulf-intl/ index.html

\section{Lions in Zambia cross areas thought uninhabitable for them}

Zambia has c. 1,200 lions, split into two subpopulations: one in the Greater Kafue ecosystem in the west and one in the Luangwa Valley ecosystem in the east. Between them lies Lusaka, Zambia's largest city, surrounded by farmland. Because of these barriers the two groups had been thought to be geographically and genetically separated. However, researchers found through genetic analyses that a small number of lions are in fact moving across the area presumed to be uninhabitable for them, causing high levels of genetic diversity in the Zambian lion population. Scientists cannot tell precisely which way the lions are moving, but looking at where they are more closely related provides some insight. The most likely traveling route is thought to be along the Kafue River. These findings can help wildlife managers to find the actual route the felids are taking and work to maintain or increase the number of corridors to facilitate lion movements across these areas.

Source: Phys.org (2019) phys.org/news/ 2019-o9-sneaky-lions-zambia-areasthought.html 


\section{AMERICAS}

\section{Salmon scientists oppose plans for world's largest gold mine}

Over the past 2 decades, scientists have in tensively studied salmon and their habitat in Bristol Bay, Alaska. Tens of millions of salmon return there each year, making it one of the most productive salmon fisheries. Now, a mining company wants to extract copper and gold from beneath the headwaters of two of Bristol Bay's main salmon rivers. The mine's $18 \mathrm{~km}^{2}$ open pit would be the largest in North America, infrastructure would include $125 \mathrm{~km}$ of roads and large artificial lakes full of toxic mine wastes. The mine could employ $>1,000$ people and generate revenues of USD 300-500 billion. However, opponents of the project, including Native Alaskan, fishing, and environmental groups, argue that the short-term economic benefits would pale in comparison with the long-term risks, including toxic runoff and habitat destruction. Scientists fear that even a smaller version of the mine could jeopardize the long-term health and sustainability of the Bristol Bay ecosystem.

Source: Science (2019) sciencemag.org/ news/2019/og/how-salmon-scientist-gothooked-battle-over-world-s-largest-goldmine

\section{Manicure for rare Cuban bats to aid population estimates}

Fewer than 750 Cuban greater funnel-eared bats Natalus primus remain in a singular cave on the peninsula of Guanahacabibes in western Cuba, according to preliminary results from the species' first population estimates by Zoological Society of London's EDGE of Existence programme. The researchers employed a low-tech but effective method for safely marking the bats to allow for individual identification: they used nail varnish of four different colours on the bats' nails, enabling them to create thousands of combinations for unique markings. The process is time-consuming for the researchers, but harmless to the bats. Although the cause of the mass population decline is unknown, funnel-eared bats have a naturally high vulnerability to extinction because of their specific habitat of hot caves. The Cueva la Barca population is now threatened by human intrusion and possible collapse of their cave roof as a result of thermal instability. Climate change poses a significant risk, further exacerbating the issue. Source: Zoological Society of London (2019) zsl.org/conservation/news/expeditionconfirms-less-than-750-rare-cuban-batsleft-in-last-cave-on-earth

\section{Links of drug trafficking and illegal logging in Honduras}

Illegal timber and drug trafficking are closely linked in north-eastern Honduras, a major cocaine corridor in this region. Timber trade was worth c. USD $60-80$ million during 2016-2018 in Honduras, but environmental agencies warn that 50$60 \%$ comes from illegal logging, much of it from the country's north-eastern natural reserves such as the Río Plátano Biosphere. Farmers, particularly migrants from the poorest areas of southern Honduras, settle in unpopulated lands in and around the reserve. They harvest wood illegally, often with protection from corrupt officials and politicians, and from drug trafficking groups. The mountains and plains in the area are dotted with clandestine roads and airstrips that are used to move drugs and illegally harvested precious woods, such as mahogany and cedar. The drugs arriving by plane are shipped out on long, flat boats used for river navigation, often hidden among the timber. At least three large drug trafficking groups in this region engage in illegal logging.

Source: InSight Crime (2019) insightcrime. org/news/analysis/how-drug-traffickers-

became-masters-of-honduras-forests

\section{Amphibians and trees further protected in Puerto Rico}

The Sierra de Cayey, in the south-east corner of Puerto Rico's Central Mountain Range is crucial to the country's endemic amphibians and plants, as well as to local birds. But expanding agricultural development threatens to destroy the region's forests. In the summer of 2019 Rainforest Trust and local partner Para la Naturaleza purchased 112 acres of critical habitat in the area. The acquired property sits next to the Carite State Forest and expands the Ulpiano Casal Natural Protected Area, helping to grow this vital network of protected areas. Three of the area's endemic amphibians, the Villalba robber frog Eleutherodactylus eneidae, Karl's robber frog Eleutherodactylus karlschmidti and the golden coquí Eleutherodactylus jasperi, are probably already extinct. All three are categorized as Critically Endangered, but have not been observed in at least 30 years. The new purchase prevents development in the area, helping to reduce the cumulative impact of climate change and habitat fragmentation on amphibians and other wildlife in Sierra de Cayey. Rare and endemic trees such as the Critically Endangered palo de jazmin will also benefit.

Source: Rainforest Trust (2019) rainforesttrust.org/amphibians-and-trees-furtherprotected-in-puerto-rico
Brazil sees worst rainforest fires in history. .

It came, witnesses said, quickly and without warning. One compared it to the 'apocalypse'. São Paulo-the largest city in the Americas-was plunged into afternoon darkness after vast plumes of smoke from forest fires burning across the continent suddenly swept over the city. Brazilians living in the coastal metropolis saw day turned to night for more than 1 hour. Pictures posted to social media by alarmed residents, many unsure what was happening, show the city in near pitch black. Experts have indicated the phenomenon was at least partially caused by the often deliberate and illegal burning of South America's vast swathes of forests to make way for settlement, farmland and cattle ranching. The blackout came on the same day new figures showed Brazil's Amazon rainforest has seen a record number of fires last year. The country's National Institute for Space Research said it had detected more than 72,00o blazes during January-August 2019, the highest number since records began in 2013, and an $83 \%$ increase on the same period in 2018 . Source: The Independent (2019) independent. co.uk/news/world/americas/amazon-firebrazil-rainforest-bolsonaro-sao-pauloglobal-warming-climate-change-a9072596. html

\section{.and at least $\mathbf{5 0 0}$ jaguars affected by} Amazon fires

The fires in the Amazon forest in Brazil and Bolivia last year have burned key habitats of at least 500 adult, resident jaguars, as estimated in September 2019 by experts at Panthera, the global wild felid conservation organization. The researchers used the total area of jaguar habitat burned and combined this with a jaguar density estimate of 2.5 individuals $/ 100 \mathrm{~km}^{2}$ derived from a 2018 study. The numbers were expected to further increase until the arrival of rains. In Bolivia in particular, the fires had destroyed over 2 million ha of forest in one of South America's key areas for wild felids, a region with the highest predicted density of felid species on the continent. Fires not only destroy critical habitats, they also fragment forests, reducing connectivity between habitats that animals need to live and thrive. Researchers also predicted jaguars may starve or turn to killing livestock in neighbouring ranches as a consequence of the fires, increasing the likelihood of negative interactions with ranchers and jeopardizing decades of conservation efforts.

Source: Mongabay (2019) news.mongabay. com/2019/og/panthera-at-least-50ojaguars-lost-their-lives-or-habitat-inamazon-fires 


\section{ASIA \& OCEANIA}

\section{At least two dead tigers seized weekly from smugglers}

More than two carcasses of Endangered tigers are being seized every week from smugglers. Officials in 32 countries discovered 2,359 dead tigers between 2000 and 2018 (a mean of 131/year), but the real number of smuggled tigers is likely to be higher. In Indonesia a dozen skins were found in August 2019 in a workshop making traditional dance masks. More than half (58\%) of the tigers seized in Thailand and $30 \%$ in Viet Nam came from tiger breeding farms, where tigers are reportedly often kept in appalling conditions, and which are considered to stimulate demand for the animal products and undermine conservation efforts. Only c. 3,900 wild tigers remain, in 13 countries across Asia. Their habitats are being destroyed and they are hunted illegally for their skins, bones and meat, with tiger parts used widely in Traditional Asian Medicine. Sources: TRAFFIC (2019) traffic.org/site/ assets/files/12344/skin-and-bonesunresolved-1.pdf \& The Independent (2019) independent.co.uk/news/world/asia/tigerssmuggle-poaching-skin-breeding-farmextinct-asia-a9073161.html

\section{Malaysia's next generation of conservation leaders}

The Malaysian Nature Society (MNS), which has long played a leading role in conservation in Malaysia, is working with BirdLife International through an EU-funded project seeking to increase participation in forest governance and advocacy. MNS's mission, to effectively protect the country's natural heritage and rich biological diversity, is receiving a boost through capacity building and training for early-career staff and volunteers provided by BirdLife International's Local Engagement and Empowerment Programme. The training is designed to help stem forest loss by ensuring effective participation in conservation interventions, as well as access to tools that can increase the likelihood of successful implementation. Training on project management and Theory of Change development (ways to plan, monitor, and evaluate impacts) was linked back to MNS's strategy and vision, to help staff and volunteers apply these approaches to their ongoing efforts across all departments in the organization, and equip the next generation of conservationists with tools and methods to support their work. Source: BirdLife International (2019) birdlife. org/worldwide/news/malaysia\% $\% 2 \% 80 \%$ 99s-next-generation-conservation-leaders

\section{Helping Mongolia's falcons}

Falcon populations are struggling in Mongolia, where thousands of raptors are electrocuted every year. Researchers have been working to reduce the number of Endangered saker falcons Falco cherrug electrocuted on power lines, using a number of different techniques. The species' habitat is threatened by development, but Mongolia still has a relatively large population. After the collapse of Soviet rule, Mongolia started to replace c. 30,0oo wooden power line poles with steel reinforced concrete poles. These are dangerous for birds because they are grounded. Because in the vast grasslands the poles are the only places for the raptors to perch, hundreds of birds can die when they congregate around these structures after the breeding season to feed on rodents on the steppe. By reconfiguring the tops of the poles researchers found they could deter the birds from perching on them, reducing the electrocution rate by c. $85 \%$. Rotating mirrors that flashed reflections from the sun were also effective, but were easily broken and had to be replaced often. Covering parts of the pole to prevent grounding requires less maintenance and has a longer lifespan, making it a more cost-effective solution.

Source: The Wildlife Society (2019) wildlife. org/wild-cam-reducing-mongolian-falcondeaths

\section{Two endemic snail species reintroduced to French Polynesia}

Two species of tropical snail have been returned to their native French Polynesia, 25 years after they were wiped out by a human-introduced invasive species. The predatory rosy wolf snail was introduced to rid the Society Islands of a previously introduced alien species, the African giant land snail, but unfortunately it targeted the endemic snails instead. The Zoological Society of London worked with other leading zoos and the French Polynesian government to coordinate a conservation breeding programme involving the progeny of the last individuals found in the Society Islands in the 1990s. In 2019 the reintroduction focused on two species categorized as Extinct in the Wild, Partula rosea and Partula varia, with several thousand being carefully transported over $15,000 \mathrm{~km}$ from the UK to the French Polynesian islands. The effort was part of the world's largest reintroduction programme, with 14 snail species and subspecies reintroduced over the last 5 years.

Source: Zoological Society of London (2019) zsl.org/conservation/news/two-extinct-inthe-wild-partula-snail-species-returned-tothe-wild-for-first-time

\section{Plastic ingestion affects seabirds' growth and health}

Researchers studying sublethal impacts of plastic pollution on seabirds have shown that ingestion of plastic particles causes a host of health issues. Analysis of blood samples from a population of Near Threatened flesh-footed shearwaters on Lord Howe Island, off the eastern coast of Australia, found the birds were living with a litany of problems after eating plastic debris, with impacts ranging from high cholesterol and reduced blood calcium levels to impaired kidney function. Plastic ingestion also led to shorter wings and bills, and lower body mass. Instead of fish, adults have been feeding their chicks small pieces of plastic, which researchers believe is contributing to the birds' decline. Previous research has shown that almost all seabirds are ingesting plastic, and it is possible that many species are similarly affected.

Source: CNN (2019) edition.cnn.com/2019/ o7/3o/health/seabirds-plastic-pollutionhealth-problems-scli-intl/index.html

\section{Declines of Myanmar's coral reefs}

Experts have warned that Myanmar's coral reef cover has declined by $70 \%$, but the actual figure is difficult to ascertain because of a lack of data. During a 2019 meeting to create a national action plan to protect sharks and manta rays, experts said that coral reefs in Myanmar remain largely unexplored, and little is known about their species diversity and health. Most coral reefs are found in Rakhine and Tanintharyi coastal areas, particularly around the Mergui Archipelago. The experts said the main culprit in the decline of coral cover is blast fishing and the use of illegal small meshed fishing nets that destroy the coral. There is also the unregulated extraction of coral. The Wildlife Conservation Society of Myanmar underscored the need for more studies to develop an effective conservation and monitoring strategy.

Source: Myanmar Times (2019) mmtimes. com/news/experts-say-7o-nations-coralreefs-are-damaged.html

All internet addresses were up to date at the time of writing. The Briefly section in this issue was written and compiled by Emma Muench, Julia Hochbach and Martin Fisher, with additional contributions from Ben Jobson, Hannah McCormick and Annkathrin Sharp. Contributions from authoritative published sources (including websites) are always welcome. Please send contributions by e-mail to oryx@faunaflora.org. 